\title{
PERGULATAN AGAMA DALAM PERUBAHAN BUDAYA: Merespon Perubahan Budaya Interaksi Masyarakat melalui Situs Jejaring Sosial
}

\author{
A6dul Bashith \\ Fakultas Tarbiyah UIN Maulana Malik Ibrahim Malang. \\ Jalan Gajayana No. 50 Malang. Telp. 0341-551354, HP. 08125263521 \\ email: abbash98@yahoo.co.id
}

\begin{abstract}
The present reality of modern life mainstreaming of information and interaction as a source of capitalization of the search values, like maintaining a fire. If the use is quite proportional, then the technology and information into one medium that can deliver the deep nature of human life. But on the other hand, information technology and human interaction can be bamboozling in understanding the reality of what happened. The phenomenon that is now implicated in the use of social networking. Regardless of what people do routine, always expressed, reflected and internalized into the social networking site. The existence of increasingly affirms the social networking site to meet the desires of the way humans interact, but not infrequently social networking is also capable of carrying humans to the space that is "gray" zone between private and public sectors.
\end{abstract}

Realitas kehidupan modern yang menyajikan teknologi informasi dan interaksi sebagai sumber kapitalisasi pencarian tata nilai, bagaikan memelihara api. Jika penggunaannya cukup proporsional, maka teknologi dan informasi menjadi salah satu medium yang mampu mengantarkan manusia mendalami Hakikat kehidupan. Namun di sisi lain, teknologi informasi dan interaksi dapat meninabobokan manusia dalam memahami realitas yang terjadi. Fenomena itulah yang kini menggejala dalam praktik jejaring sosial. Apapun rutinitas yang dilakukan manusia, selalu diungkapkan, direfleksikan dan diinternalisasikan ke dalam situs jejaring sosial. Keberadaan situs jejaring sosial kian meneguhkan 
cara manusia untuk memenuhi hasrat dalam berinteraksi, tetapi tidak jarang jejaring sosial juga mampu menggiring manusia kepada ruang yang "abu-abu" antar zona privat dan publik.

Key words: social networking, interact, values

\section{Interaksi Manusia dalam Jejaring Sosial}

Globalisasi membawa perubahan dalam kehidupan manusia, tidak terkecuali dalam hal cara mereka berinteraksi dan berkomunikasi. Eksistensi manusia ditandai dengan adanya interaksi terhadap sesamanya. Manusia merupakan mahluk sosial yang keberadannya diciptakan dalam interaksi sosial (Lauer, 1993: 277). Oleh karena itu, interaksi tidak bisa dipisahkan dalam kehidupan masyarakat modern. Untuk itu, interaksi akan terus berkembang seiring semakin mutakhirnya medium yang dipergunakan.

Berkembangnya medium interaksi sosial melalui jejaring sosial seperti facebook dan twitter merupakan sebuah fenomena baru dalam interaksi manusia modern. Keduanya, fecebook dan twitter merupakan jenis jejaring sosial yang paling populer saat ini. Media facebook dicetuskan oleh Mark Zuckerberg dibantu oleh Eduardo Saverin, Dustin Moskovitz dan Chris Hughes pada tahun 2004. Pada saat itu, mereka semua adalah para mahasiswa pada sebuah perguruan tinggi ternama di Amerika. Sementara Twitter dipopulerkan oleh Jack Dorsey pada tahun 2006 (Wikipedia, 2001: 1).

Semangat berbagi pesan dengan sesama merupakan titik pertemuan dari dua jejaring sosial terpopuler saat ini. Jejaring sosial tersebut mampu membuat manusia seakan "telanjang" tentang dirinya, keluarga bahkan rahasia yang terkadang bersifat tabu untuk dibicarakan, dikomunikasikan dan dibagi kepada manusia lain. Sudah menjadi bagian dari keseharian manusia, bahwa berinteraksi layaknya makan dan minum, ia membutuhkan pengisian dan respon setiap hari. Tanpa itu semua kehidupan manusia menjadi kurang berarti dan tidak meninggalkan sejarah apapun.

Tidak ada alasan tunggal mengapa seseorang sekarang lebih suka mengungkapkan kesehariannya melalui jejaring sosial. Namun demikian, adanya jejaring sosial dapat memberi informasi kepada semua orang tentang bagaimana jatidiri seseorang tertentu tanpa harus mengenal dan bertegur sapa dengannya. Dua peyangga interaksi sosial adalah manusia sebagai (a) individu dan (b) sosial. Hubungan keduanya saling mempengaruhi dan bersifat timbal balik antara keduanya.

Interaksi mempengaruhi perilaku seseorang dan benda-benda yang ada 
disekitarnya. Secara lebih lanjut diilustrasikan seperti bayi yang baru lahir dalam keadaan lemah, keadaan bayi ini mempengaruhi orang lain, seperti ibu dan perawat untuk menolong dengan penuh cinta kasih dan berhati-hati untuk merawatnya (Ahmadi, 1982: 45). Selain itu, interaksi pertama kali yang dilakukan manusia tidak terjadi di dunia melainkan jauh sebelumnya yakni di surga (Huda, 2008: 2). Hal demikian sebagaimana ditegaskan oleh Allah SWT dalam QS Al Baqarah ayat 30:

Ingatlah ketika Tuhanmu berfirman kepada Para Malaikat: "Sesungguhnya aku hendak menjadikan seorang khalifah di muka bumi." mereka berkata: "Mengapa Engkau hendak menjadikan (khalifah) di bumi itu orang yang akan membuat kerusakan padanya dan menumpahkan darah, Padahal Kami Senantiasa bertasbih dengan memuji Engkau dan mensucikan Engkau?" Tuhan berfirman: "Sesungguhnya aku mengetahui apa yang tidak kamu ketahui" (QS Al Baqarah: 30).

Dengan memperhatikan dan memahami penjelesan di atas semakin memperjelas bahwa keberadaan situs jejaring sosial menjadi alternatif medium interaksi di tengah kehidupan masyarakat diantara berbagai alternatif saluran yang ada. Namun keberadaannya menimbulkan problem dilematif dalam tatanan kehidupan sosial. Orang tidak lagi sungkan dan canggung untuk menghujat, mengekplorasi hasrat tubuh, berinteraksi, dan berdialog tentang kesadaran dirinya yang bersifat privacy untuk dipertontonkan ke depan publik. Seakan-akan, ruang tabu yang bersifat pribadi dihadirkan untuk sekedar mendapat komentar dan perhatian.

Kosakata yang muncul dalam jejaring sosial menggambarkan ekspresi pengalaman hidup manusia yang didalamnya membawa muatan pengetahuan, pandangan hidup, keyakinan maupun pemikiran mereka. Oleh karena itu, kemampuan berbahasa dan berinteraksi masyarakat melalui apapun media yang digunakan mencerminkan keseluruhan perkembangan politik, sosial dan sejarah budaya masyarakat tersebut. Hal demikian memperjelas sejarah perkembangan kemampuan bahasa verbal manusia yang dipicu oleh kemampuan berinteraksi diantara sesama (Baugh dkk, 1978: 2).

Dengan demikian perbicangan pergeseran serta perubahan budaya masyarakat dalam berinteraksi terhadap sesamanya menjadi semakin menarik untuk dibicarakan, diantaranya adalah dalam hal pemanfaatan situs jejaring sosial yang keberadaannya di tengah kemajuan dan kemutakhiran teknologi komunikasi dan informasi tidak dapat dinafikan. Bahkan, sudah menjadi bagian dari perkembangan peradaban kehidupan manusia di zaman modern 
sekarang ini. Pergulatan panjang dalam penyikapan fenomena tersebut semakin tajam dan mendalam jika dikaitkan dengan kajian keagamaan, sehingga memperjelas dan mempertegas peran agama dalam perkembangan kehidupan manusia mengikuti peradabannya.

\section{Legalitas Situs Jejaring Sosial}

Keberadaan situs jejaring sosial tidak dapat dihindarkan dalam kehidupan manusia, mau tidak mau, siap tidak siap, bisa dan tidak bisa, keberadaannya ada di tengah-tengah masyarakat. Maka dari itu, perlu diperjelas tentang legalitas situs jejaring sosial tersebut agar manusia tidak gamang dan ragu dalam memanfaatkannya. Dalam pandangan Yusuf Qardhawi dinyatakan dengan tegas bahwa di mana ada maslahat, di sanalah hukum Allah. Jika dikaitkan dengan keberadaan situs jejaring sosial, sepanjang keberadaannya baik dan membawa kemaslahatan tentunya manfaat pula bagi kebaikan kehidupan manusia. Namun begitu pula sebaliknya. Maka dari itu dikembalikan lagi pada manusianya yang menjadi subyek sekaligus objek dari keberadaan situs jejaring sosial. Keberadaanya legal untuk kebaikan dan tidak dibenarkan untuk disalah gunakan pada hal hal yang mendatangkan kemudharatan bagi kehidupan manusia itu sendiri (Qardhawi, 1994: 68).

Salah satu fenomena nyata pemanfaatan situs jejaring sosial untuk kemaslahatan dan perubahan positif dalam masyarakat dapat diilustrasikan dari kisah seseorang yang berpisah puluhan tahun dengan orang yang dicintainya dipertemukan kembali dengan adanya jejaring sosial. Inilah sisi positif dari jejaring sosial yaitu mampu menumbuhkan صلة الرحم (menyambung tali persaudaraan). Dalam hal dan kesempatan yang lain, jejaring sosial juga dapat digunakan untuk penggalian dana agar anak-anak yatim dan fakir miskin mampu terpelihara dengan baik (البرياليتامى والمساكين). Pada bagian yang lain, dapat dilihat pada kasus bibit dan Chandra saat terjadi kriminalisasi Komite Pemberantasan Korupsi (KPK) menunjukkan bahwa jejaring sosial mampu menumbuhkan spirit التكافل والتضامن (bahu membahu dan solidaritas).

Namun tidak jarang, jejaring sosial juga masih digunakan untuk hal hal yang tidak baik dan tidak bermanfaat, bahkan membawa kemudharatan bagi manusia itu sendiri. Hal demikian sangat dimungkinkan terjadi karena situs jejaring sosial juga mengizinkan seseorang untuk melakukan perbuatan tercela dengan membolehkan seseorang menulis akunnya dengan perkataan-perkataan yang bersifat غيبة (menggunjing), نميمة (mengadu domba), الحسـدوالحقد (dengki dan iri hati), dan أناني (egoisme). Ini yang menjadikan situs jejaring sosial 
layaknya pisau bermata dua. Dia dapat digunakan sebagai pisau yang mampu menunjukkan kebenaran dan kesolidan, tetapi di sisi lain ia juga mampu membunuh karakter seseorang tanpa harus menikamnya secara langsung.

Hal demikian merupakan imbas dari sistem jejaring sosial yang didesain untuk mengetahui apa yang dipikirkan dan dirasakan seseorang, tanpa perlu lagi repot-repot menemuinya, melainkan dengan melihat update statues yang diposting seseorang tersebut dapat diketahui apa yang dipikirkan dan dirasakannya saat ini. Semuanya dikembalikan lagi kepada manusianya, sebagai pengguna situs jejaring sosial, karena manusialah yang menjadi subyek sekaligus objek dari keberadaannya.

Oleh karena itu, ruang interaksi dalam jejaring sosial itu kini juga mempunyai rambu-rambu. Hal hal yang dilarang dalam penggunaan jejaring sosial dalam UU No. 11 tahun 2008, meliputi:

1. Menggunakan jejaring sosial sebagai untuk melakukan pelanggaran kesusilaan.

2. Menggunakan jejaring sosial sebagai muatan perjudian.

3. Menggunakan jejaring sosial sebagai muatan penghinaan dan/atau pencemaran nama baik.

4. Menggunakan jejaring sosial sebagai muatan pemerasan dan/atau pengancaman.

5. Menggunakan jejaring sosial sebagai penyebaran berita bohong dan menyesatkan yang mengakibatkan kerugian orang lain.

6. Menggunakan jejaring sosial ditujukan untuk menimbulkan rasa kebencian atau permusuhan individu, kelompok masyarakat tertentu berdasarkan atas suku, agama, ras, dan antargolongan (SARA).

7. Menggunakan jejaring sosial untuk menyebarkan berita bohong dan menyesatkan Menggunakan jejaring sosial untuk menyebarkan informasi yang ditujukan untuk menimbulkan rasa kebencian atau permusuhan individu dan/atau kelompok masyarakat tertentu berdasarkan atas suku, agama, ras, dan antargolongan (SARA).

\section{Jejaring Sosial sebagai Sebuah Kelanjutan Fungsi Interaksi}

Kehidupan manusia modern yang semakin komplek meniscayakan bantuan teknologi informasi dan komunikasi. Hal ini dilakukan agar manusia mendapatkan kemudahan dalam menjalani kehidupannya. Jika penggunaannya cukup proporsional, maka teknologi dan informasi menjadi salah satu medium yang mampu mengantarkan manusia mendalami Hakikat kehidupan. Namun 
di sisi lain, teknologi informasi dan interaksi dapat menina bobokan manusia dalam memahami realitas yang terjadi. Sehingga yang pada awalnya teknologi informasi dan interaksi yang dipergunakan sebagai medium mencari sesuatu, tidak jarang malah berubah menjadi fungsi menjadi titik akhir manusia dalam pencarian Hakikat kehidupan.

Entah fenomena apa yang sedang terjadi, seakan-akan tatanan nilai-nilai kehidupan yang sudah mapan seperti agama dan budaya sedikit demi sedikit mulai diminimalisasi atau dikerdilkan manusia itu sendiri. Hanya dalam peristiwa-peristiwa tertentu yang dianggap penting saja manusia modern berpulang kepada agama dan budaya. Seakan-akan agama dan budaya adalah emergency door, sebuah pintu yang akan dilalui manusia manakala masalah yang dihadapinya sudah tidak dapat diatasinya lagi.

Manusia sepertinya akan melakukan tindakan sesuatu ketika dia telah memahami makna tertentu. Dalam situs jejaring sosial, pola bahasa interaksi yang digunakan umumnya pendek namun lugas dengan menunjukkan makna yang spesifik. Karakteristik bahasa tersebut nampaknya berpengaruh terhadap perilaku manusia lain untuk bertindak terhadap suatu berdasarkan makna-makna yang ada. Hal demikian semakin memperjelas yang dinyatakan oleh Paloma dalam bukunya bahwa pengembangan makna yang dilontarkan seseorang, seringkali melebihi dari apa yang telah ditulisnya, sehingga proses interaksi yang dihasilkan dari interaksi jejaring sosial semakin sempurna bahkan saat proses interaksi sosial itu berakhir (Paloma, 1987: 261).

Bahasa tulis dalam jejaring sosial memiliki kekayaan informasi daripada ketika seseorang menggunakan bahasa lisan. Pemilihan medium interaksi yang lebih informatif akan lebih bermakna, yang menunjukkan bahwa interaksi tersebut kaya dengan keterangan, pernyataan, gagasan, dan tanda-tanda yang mengandung nilai, makna, dan pesan, baik data, fakta maupun penjelasannya yang dapat dilihat, didengar, dan dibaca yang disajikan dalam berbagai kemasan dan format sesuai dengan perkembangan teknologi informasi dan komunikasi secara elektronik ataupun nonelektronik (UU No. 14 tahun 2008).

Hasil survey yang dilakukan oleh salah satu majalah teknologi informasi tentang perilaku pengguna situs interaksi sosial dilaporkan bahwa perkembangan interaksi sosial yang begitu masif dalam jejaring sosial dipengaruhi oleh: pertama, adanya hubungan yang begitu kuat antara si pemberi pesan (pihak yang meng-update statues) dengan si perespon. Meskipun hal itu terjalin dengan sangat instan, namun membawa makna yang tidak jarang memberi kesan yang mendalam. Ironisnya, terkadang pengaruh interaksi juga tidak 
berlangsung lama. Demikian cepat mendapat respon, akan tetapi di sisi lain juga orang akan mudah melupakannya. Kedua, interaksi yang dilakukan melibatkan berbagai pihak sehingga menimbulkan berbagai simpati dan antusias. Ini yang kemudian pernyataan-pernyataan yang dilontarkan dalam jejaring sosial terlihat sebagai masalah bersama kelompok, meski sebenarnya adalah masalah pribadi pengunggah. Ketiga, lontaran update-statues ataupun lontaran-lontaran dari jejaring sosial memiliki karakteristik problematif. Ini yang menyebabkan si perespon merasa terpanggil untuk memberi komentar atau sekedar memberi dukungan-dukungan positif.

Selanjutnya dalam bayangan pemakai jejaring sosial, adanya respon merupakan bentuk kepedulian. Bagaimana bentuk respon, postitif maupun negatif, terkadang dikesampingkan. Semuanya menjadi sangat reaktif, unprediktif, subyektif, ilustratif, dan komunikatif. Dapat dikatakan seakanakan batasan sudah tidak terbatas lagi ruang dan waktu untuk saling bertemu lalu saling mengadu.

\section{Islam di Tengah Perubahan Kultur Interaksi Jejaring Sosial}

Satu pertanyaan besar dan mendalam adalah mungkinkah jejaring sosial dapat menjadi medium interaksi modern dalam menyampaikan pesan dan nilai moral agama? Ini menjadi sebuah tantangan akses informasi di tengah semakin beragamnya seseorang dalam mengakses pintu pencarian Hakikat kehidupan. Dari segi historisnya, tren interaksi yang berkembang di tengah masyarakat nampaknya menjadi ajang paling efektif dalam mengenalkan sekaligus menginternalisasikan nilai-nilai yang dianggap sebagai kebaikan (virtue) ke dalam ruang publik..

Sebagai suatu contoh perumpamaan tentang keberadaan media interaksi sosial yang dulu pernah digunakan oleh wali dalam penyebaran ajaran agama islam adalah wayang. Keberadaan wayang digunakan para wali sebagai alat untuk menyebarkan agama Islam (da'wah islamiyah). Pagelaran wayang diselenggarakan oleh para wali dengan Sunan Kalijaga sebagai dalangnya. Musik pengiringnya menggunakan gamelan sekaten yang dimiliki oleh Syekh Syarif Hidayatullah, sebagai hadiah dari Sultan Demak. Ketika itu, masyarakat masih banyak yang memeluk agama Hindu, Budha, dan animisme, yang umumnya senang mendengarkan cerita wayang (Nasuha, 2010: 4).

Wayang merupakan bentuk media masyarakat tradisional menginteraksikan secara sosial tentang suatu tatanan nilai. Ia begitu memesona khalayak sehingga keberadaannya tidak hanya dimaknai sebagai sarana seni atau hiburan saja. 
Akan tetapi lebih dari itu, wayang menjadi medan magnet budaya yang mampu membumikan nilai-nilai ke-Islam-an sehingga terasa sekali bahwa agama tersebut dekat dan menjadi bagian yang tidak terpisahkan dalam kehidupan masyarakat.

Agama merupakan seperangkat aturan dan peraturan yang mengatur berbagai tingkatan hubungan. Agama hadir dihadapan manusia untuk mengatur hubungan manusia dengan dunia gaib, manusia lainnya, maupun dengan lingkungannya (Roberton, 1995: 5). Dinyatakan lebih lanjut bahwa wayang dalam penyebaran agama memegang fungsi penting sebagai media untuk mendapatkan gambaran tentang bagaimana menemukan pandangan hidup (way of life). Selanjutnya, pandangan hidup tersebut menjadi tumpuan tujuan dari kehidupan manusia yang bersumber pada ajaran agama. Dengan kata lain dapat diartikan bahwa tata kehidupan keseharian umat manusia senantiasa mengacu kepada norma-norma yang bersumber dari ajaran agama.

Ditetapkannya wayang sebagai salah satu warisan dunia, melahirkan sebuah harapan baru untuk memajukan hasil kebudayaan tersebut. Wayang tidak sekedar hasil budaya, ia juga mengandung makna dan kekayaan penghayatan kehidupan. Transformasi kesejarahan Indonesia, Islam dan kebudayaan tersimpan dalam wayang. Ini berarti keberadaan wayang mengintegrasikan tiga kekuatan besar yang menjadikan Indonesia sebagai arus pertemuan agama, kebangsaan dan keagamaan yang begitu hebat. Meskipun pementasannya lebih terkonsentrasi pada zona hiburan, wayang tetap eksis dimaknai sebagai salah satu pusat budaya dan pengantar memahami makna-makna nilai-nilai agama yang tersimpan didalamnya.

Hal demikian dikarenakan pada zaman dahulu, wayang sebagai wadah interaksi sosial yang mampu menembus sekat-sekat stratifikasi sosial yang begitu melekat, seperti adanya golongan bangsawan, keluarga kerajaan dan rakyat jelata. Adanya pelekatan egalitarianisme dalam wayang menyebabkan keberadannya begitu melegenda.

Lalu pertanyaannya, bagaimana jejaring sosial yang sesungguhnya juga memiliki kemiripan karakter egalitarianisime seperti wayang? Melihat perkembangan jejaring sosial yang dari hari ke hari semakin menunjukkan perkembangan penggunaannya, maka bisa jadi jejaring sosial akan memiliki kesejarahan yang lama dan melegenda seperti wayang. Penyikapan yang positif terhadapnya akan melahirkan kebaikan dan kemaslahatan, begitu pula sebaliknya, penyikapan yang negatif akan mendatangkan kejelekan dan kemudharatan. Semuanya dikembalikan pada manusia sebagai subyek 
sekaligus objeknya.

Mengkaji visual magis jejaring sosial tidak terlepas dari pola perilaku interaksi masyarakat sekarang. Kurang begitu mengentalnya ikatan interaksi yang terbina dari ruang keluarga, sebagai zona terpercaya dalam mencurahkan isi, perasaan, keinginan manusia, menegaskan bahwa kepercayaan manusia terhadap keluarga intinya terutama dalam aspek interaksi semakin terkikis. Ada keengganan untuk mengungkap persoalan yang menjerat kehidupan ke dalam zona keluarga. Mereka lebih suka menuangkannnya dalam bahasa tulis sebagaimana dapat disaksikan dalam update status-nya.

Sebagai media interaksi yang dapat diakses kapan pun, jejaring sosial tidak secara penuh menggambarkan adukan interaksi yang diletupkan oleh seseorang. Itu berarti tidak secara keseluruhan perasaan, hati, hingga pemikiran seseorang terungkap di media sosial tersebut. Meski demikian, respon interaksi yang terpicu dari lontaran update status tersebut selalu ada.

Kepedulian merespon interaksi di dunia maya jauh lebih tinggi frekuensi balikannya daripada interaksi yang dilaksanakan dengan cara interaksi secara kontak fisik. Meskipun, interaksi tatap muka akan membawa nilai kejujuran yang lebih mendalam dari pada bahasa tulis. Dengan interaksi tatap muka pun akan membawa kekuatan emosi yang lebih kuat daripada sekedar dengan bahasa tulis. Ini yang menyebabkan interaksi tatap muka mampu menyentuh sisi kemanusiaan yang paling sensitif daripada interaksi bahasa tulis yang terkadang ditemui adanya kesenjangan antara yang tertulis dengan apa yang dibatinkan dan dipikirkan.

Jika seseorang masih belum mau berinteraksi meskipun sudah ada jejaring sosial pada umumnya ada tiga hal yang melatar belakanginya yakni; pertama, prasangka historis. Ada traumatisasi menggunakan jejaring sosial yang telah di-hack kadangkala membuat seseorang antipati terhadap jejaring sosial tersebut. Selain itu, adanya pengalaman buruk menggunakan jejaring sosial seperti penipuan keuangan ataupun trafficking (penjualan manusia) menjadikan seseorang antipati terhadap jejaring sosial. Kedua, perlakuan diskriminasi. Seseorang tidak tertarik untuk berinteraksi karena mengalami diskriminasi informasi dan perlakukan baik itu dari teman atau follower-nya. Ketiga, in-group feeling yang berlebihan dengan menganggap inferior pihak yang lain (out-group). Perasaan rendah diri dan minder untuk bergabung dengan komunitas menjadikan seseorang juga terlihat pongah untuk melakukan interaksi melalui jejaring sosial (Purwasito, 2003: 147).

Selain beberapa faktor di atas, seseorang enggan melakukan interaksi 
sosial dikarenakan ketiadaan waktu, gagap teknologi dan memang tidak tertarik untuk menggunakan jejaring sosial sebagai wadah berinteraksi dengan jejaring sosial. Hal ini biasanya banyak dijumpai pada kalangan masyarakat kuno yang hidup di pelosok dan kurang berpendidikan.

Kemunculan jejaring sosial menunjukkan bahwa masyarakat masih membutuhkan wadah interaksi yang tidak terlibat (intangible) untuk memenuhi kebutuhan dasarnya sesama manusia yaitu berinteraksi. Kesesuaian interaksi nyatanya juga membutuhkan kesamaan perspektif antara komunikator dan penerima. Perspektif yang dimaksud adalah adanya ragam bahasa yang disetujui sebagai gaya interaksi yang egaliter, mencair, tidak terlalu formal dan terkadang memiliki karakter solutif. Jejaring sosial lebih dipilih sebagian manusia modern dalam melampiaskan curahan hati. Bahkan tidak jarang persoalan kehidupan pun dicarikan jawabannya melalui media tersebut. Penyampaian interaksi di jejaring sosial melalui tulisan-tulisan menjadikannya memiliki makna lebih luas daripada maksud penulisnya sekalipun.

Jika ditelaah lebih mendalam, berdasarkan jenisnya, analisis Brodberk sebagaimana yang dikutip oleh Mudjia, menunjukkan bahwa makna memiliki tiga jenis yakni: pertama, makna referensial, yaitu makna suatu istilah berupa objek, pikiran, ide atau konsep yang ditunjukkan oleh istilah itu sendiri. Kedua, arti istilah itu sendiri, yaitu lambang atau istilah itu "berarti" sejauh ia berhubungan dengan istilah dan konsep yang lain. Ketiga, makna intensional, yaitu arti suatu istilah, lambang, atau teks tergantung pada maksud produsernya sendiri (Rahardjo, 2005: 46). Disampaikannya lebih jelas bahwa interaksi sosial melalui tulisan mengundang berbagai makna yang menarik bagi penerima pesan. Hal ini berkaitan dengan makna yang tersimpan dalam bahasa tulisan menyimpan berbagai imajinasi, kerangka maupun sesuatu yang lebih menarik dari bahasa lisan.

Interaksi sosial melalui tulisan rupanya lebih direspon secara cepat oleh masyarakat daripada melalui penggunaan bahasa lisan. Nampaknya masyarakat sekarang lebih menyukai bahasa tulisan untuk sekedar memberi perhatian dan pertolongan daripada dengan langsung meminta secara personal kepada masyarakat lainnya. Bahkan terkadang, bahasa yang digunakan pun berlebihan. Secara umum, orang menyebut sebuah kalimat yang berlebihan dengan istilah "lebay". Meski menggunakan bahasa dengan makna dilebihlebihkan ini (hiperbolik), nyatanya juga masih ada seseorang yang merespon interaksi sosial yang dikeluarkan seseorang. 


\section{Ideologisasi Interaksi Jejaring Sosial}

Tanpa disadari, jejaring sosial berubah menjadi sebuah tatanan ruang yang mengaburkan batas-batas ruang privasi dan ruang publik dalam diri seseorang. Bahkan pada tataran selanjutnya, jejaring sosial kian menuju sebuah ideologisasi interaksi. Ini berarti bahwa apa yang tertulis, terungkap dan tergambarkan dalam jejaring sosial merangkak menjadi sebuah sistem nilai sebagai fakta atau kebenaran oleh kelompok tertentu. Ia tersusun dari serangkaian sikap terhadap berbagai respon yang terjadi dalam proses kehidupan. Ia menyediakan sebuah potret dunia sebagaimana adanya dan sebagaimana seharusnya dunia itu bagi mereka yang meyakininya. Dengan melakukan itu, ia mengorganisir kerumitan atau kompleksitas yang besar di dunia menjadi sesuatu yang cukup sederhana dan bisa dipahami (O’Neil, 2001: 31)

Proses ideologisasi interaksi masyarakat modern memiliki dua kapasitas particular, di mana melalui ideologisasi interaksi yang bersifat particular tersebut apa yang tersampaikan dari kata, kalimat hingga perasaan seseorang dianggap sebagai sebuah bentuk menyembunyikan realitas yang terjadi. Selanjutnya diuraikan ciri ideologi partikular tersebut sebagai berikut: (1) Semua pernyataan yang keluar dari benak manusia dianggap sebagai perlawanan terhadap realitas yang terjadi. (2) Konsep partikular tentang ideologi berupaya menganalisis pada realitas yang terjadi serta berusaha mencari formulasi jawaban yang tepat terhadap kenyataan yang terjadi dengan membuat ukuran kebenaran secara bersama dengan orang yang dianggap respek dan mempunyai perspektif sama dengannya (O’Neil, 2001: 32).

Dengan merekonstruksi kerangka pemikiran tersebut, dewasa ini situs jejaring sosial rupanya tidak lagi hanya sebagai ajang curahan hati, namun sudah lebih jauh itu. Penggunaan jejaring interaksi sosial sudah menjadi gaya hidup dan di satu sisi ada yang membentuk pola pikir dan alam bawah sadar seseorang untuk melakukan interaksi apapun dengan jejaring sosial.

Dalam kehidupan masyarakat modern dewasa ini, jejaring sosial berpotensi mempunyai dominasi yang begitu kental dalam pola interaksi kehidupannya. Pola pembentukan potensi proses ideologisasi jejaring sosial dalam kehidupan masayarakat modern dewasa ini dapai diperjelas dengan ilustrasi gambar berikut ini: 


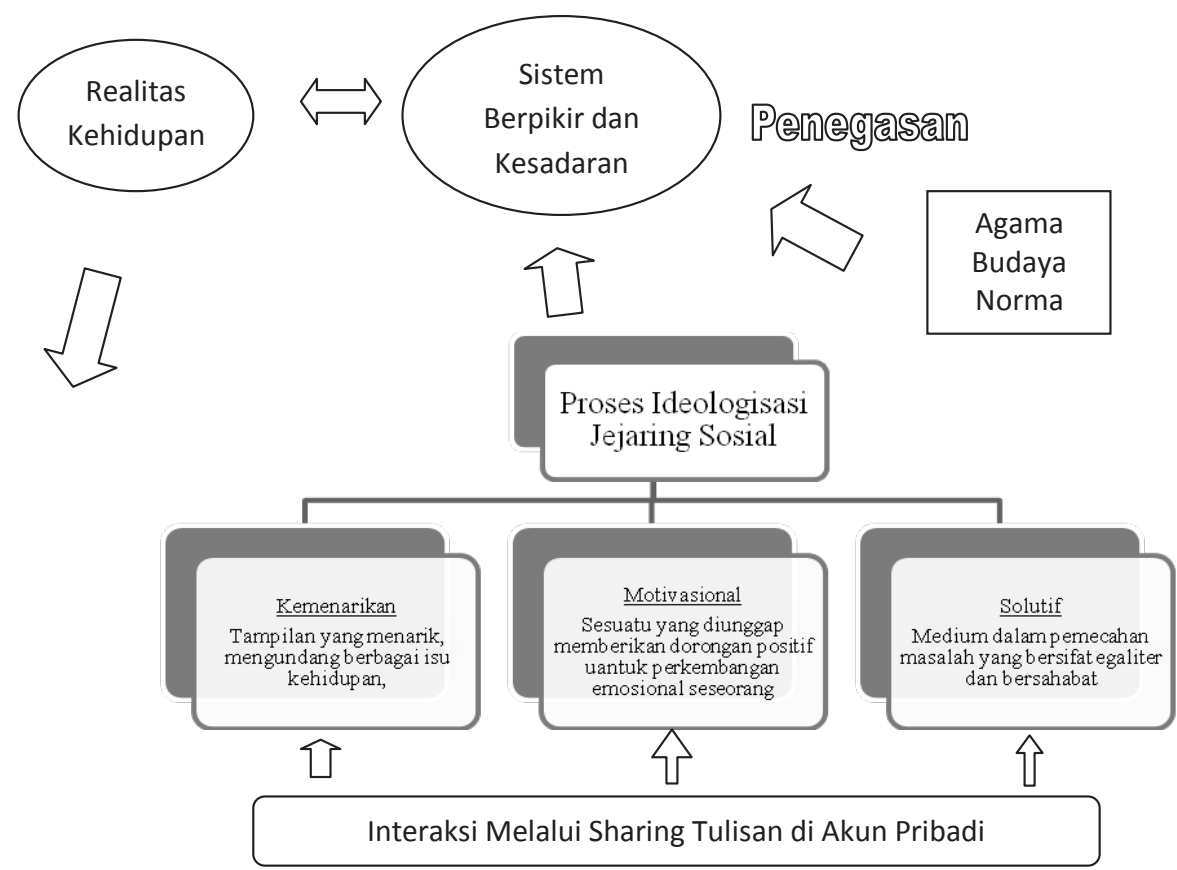

Gambar 1. Potensi proses ideologisasi jejaring sosial

Pada gambar tersebut ditunjukkan bahwa dalam menghadapi realitas kehidupan modern, sebagian masyarakat menggunakan situs jejaring sosial untuk membaca, menafsirkan bahkan mencari jawabannya. Interaksi pun dilakukan dengan mem-posting berbagai pernyataan yang menggambarkan realitas kehidupan. Jika ditemui respon yang diberikan mengandung kemenarikan, motivasional dan solutif, maka masyarakat akan menjadikan sebagai ideologi yang memainkan sistem berpikir dan kesadaran. Proses keputusan untuk menjawab realitas kehidupan pun lebih banyak dipengaruhi oleh dialektika yang diperoleh dari proses interaksi di dalam jejaring sosial.

Apabila diidentifikasi, terdapat tiga unsur yang mempengaruhi seseorang mengambil keputusan terhadap realitas kehidupan yang dihadapinya melalui jejaring sosial, yakni pertama, tampilan menarik yang membuat semua penasaran dan merasa ketagihan untuk berbagi permasalahan yang sekaligus antara satu dengan yang lain saling memberi respon. Ini yang menguatkan rasa solidaritas sosial di antara para pengguna. Kedua, berbagai respon yang di-posting dalam jejaring sosial meninggalkan rasa empati dan motivasional yang mendalam. Hal ini berpengaruh untuk meneguhkan rasa kemanusiaan yang meski dijalin 
tanpa kesepakatan sosial sebelumnya namun nyatanya dalam waktu singkat memungkinkan lahirnya tanggung jawab sosial untuk saling mendukung satu sama lain. Ketiga, pemberian pernyataan solutif yang menjadi salah satu dasar kebutuhan seseorang untuk mengeluarkan isi hatinya pada jejaring sosial.

Meski pernyataan solutif yang diberikan tidak harus rasional ataupun ilmiah, namun yang paling disukai adalah menjawab kegelisahan hati si pengupdate status. Ketika seseorang meng-up date status-nya, maka seseorang lain pun terkadang secara serta merta meresponnya. Ada yang bernada positif, seperti rasa simpati, dukungan, penghargaan dan sebagainya. Tetapi ada pula yang bernada negatif seperti hujatan, ketidak setujuan, penolakan dan sebagainya. Hal ini didasari atas sikap dasar manusia yang berusaha untuk memahami apapun (knowing much), dan berusaha merajut kontak dan interaksi dengan manusia lainnya (being sociable).

Ketika sistem interaksi sosial yang terbangun dalam jejaring sosial, terdapat kemungkinan, bahwa masalah realitas kehidupan yang dibawa dalam jejaring sosial akan menjadi tumpuan masyarakat. Sementara agama, budaya, norma hanya akan dijadikan sebagai penegasan dari solusi hasil interaksi dalam jejaring sosial. Dengan semakin masifnya penggunaan internet dimana, gelombang penggunaan jejaring sosial akan dapat diakses siapapun, perhatian masyarakat terhadap agama, budaya dan tata nilai sebagai referensi kehidupan akan mengalami pegeseran. Hal tersebut dikarenakan, orang mulai beranjak secara kolektif untuk berbagai permasalahan dan solusi masalah kehidupan. Untuk itu, para pemuka agama, budaya dan tata nilai keluhuran sudah barang tentu dituntut melakukan ekspansi dakwah, penyemaian dan pemasifan agar masyarakat tidak sedikit demi sedikit mengalami pergeseran acuan dalam menjawab realitas sosial kehidupan.

Abdullah menyatakan bahwa perkembangan modernitas di satu sisi menyebabkan the cultural dislocation atau dislokasi kultural. Hal ini terlihat dari adanya pertemuan kultur global (penggunaan interaksi jejaring sosial) dan lokal (tata nilai dan budaya) yang membuat tempat kultural terlahir terjangkiti diskualifikasi (Abdullah, 2006: 87). Pada fase ini, akan terjadi pengaburan terhadap nilai-nilai budaya, peraturan bahkan agama, yang apabila pada tahap kritis, semua tatanan nilai itu akan menjadi "batu nisan" saja. Dampaknya apa yang berasal dari kebudayaan global akan mendominasi sedangkan pengetahuan lokal (local knowledge) berubah status hanya sebagai objek ideologi simbolik (symbolic ideology) bagi masyarakatnya. Hal ini dilakukan untuk mempertegas kembali agama sebagai fungsi yang nyata dalam referensi kehidupan sebagai 
petunjuk (al huda), penjelas (at tibyan), pembeda (al furqan), dan penyembuh penyakit (al shifa').

\section{Simpulan}

Kajian mengenai pergeseran dan perubahan budaya interaksi masyarakat melalui situs jejaring sosial dalam kehidupan masyarakat modern menjadi semakin menarik untuk diperbincangkan karena keberadaannya berjalan seiring dengan perkembangan pola hidup dan peradaban manusia dewasa ini. Keberadaan jejaring sosial sudah menjalar sedemikian rupa memasuki setiap relung dan lini kehidupan. Tidak hanya bagaimana manusia sekarang melakukan interaksi satu dengan yang lainnya, melainkan pula apa yang diimplikasikan dari pola interaksi yang pada kenyataannya sekarang sudah tidak lagi mengenal batas ruang dan waktu.

Melalui interaksi sosial dalam jejaring sosial yang begitu masif, ada sebuah paradoks yang mengemuka yaitu di satu sisi, sebagian manusia ada yang begitu sangat tertutup mengungkap siapa dirinya yang sebenarnya ketika dipertanyakan secara tatap muka dan menggunakan bahasa lisan. Namun di sisi lain, tanpa ada yang menyuruh, manusia dengan begitu terbukanya mengungkap jatidirinya dengan bahasa tulis dan tanpa harus ditemui secara fisik. Ini menandakan bahwa dunia privasi sebagai zona pribadi, nyatanya pendefinisiaanya semakin mengarah kepada titik abu-abu.

Kebiasaan berinteraksi melalui jejaring sosial akan membentuk kebiasaan (habit) seseorang lebih terbuka mengutarakan apa yang terbesit dalam benaknya. Orang akan semakin mudah mengeluarkan uneg-unegnya. Tapi yang harus menjadi catatan adalah bahwa keberadaan jejaring sosial juga masih belum mampu membawa nuansa kemanusiaan (human touch) sebagaimana yang dapat dirasakan ketika manusia dengan manusia lainnya bertemu secara fisik.

Maka dari itu, jangan sampai keberadaan jejaring sosial akan meminggirkan pola interaksi secara fisik yang memiliki nilai-nilai kemesraan, keintiman, dan ketulusan dalam hubungan dan kedekatan emosional sebagaimana yang dituntunkan dalam ajaran agama. Keberadaan jejaring sosial selayaknya diterima dan disikapi secara wajar untuk menunjang kemaslahatan kehidupan manusia. Penggunaan jejaring sosial harus dilakukan secara proporsional untuk menyeimbangkan interaksi sosial manusia yang membutuhkan interaksi secara fisik maupun melalui dunia maya.

Nilai-nilai ajaran agama seharusnya menjadi landasan utama dalam interaksi masyarakat melalui situs jejaring sosial agar perkembangan peradaban 
kehidupan manusia di era modern dengan segenap kemajuan dan kecanggihan teknologi informasi menjadi terarah. Dengan berpegang teguh pada ajaran agama manusia dapat menempatkan kedudukannya sebagai mahluk yang paling mulia di tengah gejolak perkembangan kemajuan teknologi informasi. Pengamalan ajaran agama dalam interaksi masyarakat melalui situs jejaring sosial akan membentuk peradaban kehidupan masyarakat madani yang bernilai dalam arus modernisasi dan globalisasi.

\section{Daftar Rujukan}

Abdullah, Irwan. 2006. Konstruksi dan Reproduksi Kebudayaan. Yogyakarta: Pustaka Pelajar.

Ahmadi, Abu. 1982. Sosiologi Pendidikan. Surabaya: PT Bina Ilmu.

Baugh , Albert C. dan Thomas Cable. 1978. A History of The English Language. New York: Prentice Hall Inc.

Huda, Miftahul. 2008. Interaksi Pendidikan 10 Cara Quran Mendidik Anak. Malang: UIN_Maliki Perss.

Kementerian Agama. 2019. al Quran dan Terjemahnya. Jakarta: Terbitan Kemenag (tidak diperdagangkan).

Lauer, Robert. 1993. Perspektif tentang Perubahan Sosial. Terjemahan oleh Alimandan, Jakarta: Rineka Cipta.

O'neil, William F. 2001. Ideologi Ideologi Pendidikan. Terjemahan oleh Omi Intan Naomi, Cet. 2. Yogyakarta: Pustaka Pelajar.

Poloma, Margaret. 1987. Sosiologi Kontemporer. Terjemahan oleh Tien Yosogama. Jakarta: CV Rajawali.

Purwasito, Andrik. 2003. Komunikasi Multikultural. Surakarta: Muhammadiyah University Press.

Pusat Bahasa Departemen Pendidikan Nasional. 2008. Kamus Bahasa Indonesia. Jakarta: Depdiknas.

Qardawi, Yusuf. 1994. Al Ijtihad al Mu'asir. Dar at Tauzi wa an-Nasy al Islamiyah.

Rahardjo, Mudjia. 2005. Bahasa dan Kekuasaan: Studi Wacana Politik 
Abdurrahman Wahid dalam Perspektif Hermeneutika Gadamerian. Disertasi. Surabaya: Program Doktor Universitas Airlangga.

Roberton, Rolan (Ed.). 1995. Agama: Dalam Analisa dan Interpretasi Sosiologisi. Terjemahan oleh Ah. Fedyani Saifuddin. Jakarta: Rajawali Pers. 